Nastavnička revija 2 (2021) 2, 24-52

https://doi.org/10.52444/nr.2.2.2

Primljeno: 6. lipnja 2021.

Prihvaćeno: 3. prosinca 2021.

Stručni rad

\title{
KVALITETA ŽIVOTA DJECE RAZVEDENIH RODITELJA
}

\author{
Martina JAKELIĆ, mag. med. techn. \\ jakelic.martina@gmail.com
}

Ana MUTIĆ, mag. med. techn. ana_mutic@hotmail.com

Dubravka PROTIĆ, dipl. med. techn. duda.protic@gmail.com

Škola za medicinske sestre Vinogradska Vinogradska cesta 29, 10000 Zagreb

\begin{abstract}
SAŽETAK
Cilj rada je utvrditi zadovoljstvo životom kod djece čiji su roditelji razvedeni. Istraživanje je provedeno anonimnom anketom u srednjim medicinskim školama grada Zagreba. Statističkom obradom uspoređeni su učenici roditelja koji nisu rastavljeni, učenici roditelja koji jesu rastavljeni, učenici koji imaju samo jednog roditelja. Za usporedbu učenika prema kvantitativnim varijablama korišten je t-test, dok je za usporedbu učenika prema kvalitativnim varijablama korišten hikvadrat test. U prikazu podataka korištena je aritmetička sredina, standardna devijacija te minimalne i maksimalne vrijednosti. Utvrđena je statistički značajna razlika u stupnju zadovoljstva životom općenito između učenika čiji su roditelji rastavljeni i učenika čiji roditelji nisu rastavljeni $(t=2,253 ; p=.046)$. Učenici čiji roditelji nisu rastavljeni su značajno zadovoljniji životom općenito u odnosu na učenike čiji su roditelji rastavljeni. Također, učenici čiji su roditelji rastavljeni i učenici čiji roditelji nisu rastavljeni statistički se značajno razlikuju i prema stupnju zadovoljstva životnim standardom $(\mathrm{t}=3,585 ; \mathrm{p}=.001)$, zdravljem $(\mathrm{t}=1,994 ; \mathrm{p}=.050)$ i odnosima s bližnjima $(\mathrm{t}=4,338 ; \mathrm{p}=.000)$. Učenici čiji roditelji nisu rastavljeni su u većem stupnju zadovoljni životnim standardom, zdravljem i odnosima s bližnjima u odnosu na učenike čiji su roditelji rastavljeni. Prema zadovoljstvu onime što postižu u životu značajno se razlikuju samo učenici koji imaju jednog roditelja i učenici čiji su roditelji rastavljeni $(p=.050)$. Učenici čiji su roditelji rastavljeni su u prosjeku zadovoljniji onime što postižu u životu od učenika koji imaju samo jednog roditelja. Na kraju se može zaključiti da je kvaliteta života djece razvedenih roditelja umanjena u odnosu na djecu roditelja u braku.
\end{abstract}

Ključne riječi: kvaliteta života, djeca, razvedeni roditelji

\section{UVOD}

Brak je uređena životna zajednica muškarca i žene usklađena s civilnim ili crkvenim zakonima i propisima te je temelj svake obitelji. U današnje vrijeme je institucija braka koja bi trebala biti temelj svake obitelji nije više toliko bitna kao u prošlim vremenima. Sve više je razvoda brakova u kojima se sve manje razmišlja o djeci i njihovim osjećajima 
M. Jakelić, A. Mutić, D. Protić, Kvaliteta života djece razvedenih roditelja

odnosno kako će to utjecati na njihovo psihičko stanje. Iako je u tim brakovima bilo dosta nesuglasica, svađa, ponekad i fizičkog nasilja, možda je i bolje zbog djece da se zaustavi i da djeca žive u mirnijem okruženju.

Svake godine više od milijun američke djece doživi razvod ili razdvajanje svojih roditelja. Siromaštvo, niža razina obrazovanja roditelja i roditelji koji su djeca razvoda mogu biti čimbenici razvoda (Kleinsorge, Covitz, 2012: 147-154). Roditelji djece s kroničnim ili teškim bolestima i neurorazvojnim poremećajima poput raka i poremećaja iz spektra autizma često su izloženi većem riziku od razvoda, iako neke studije pokazuju da to nije uvijek slučaj (Urbano, Hodapp, 2007: 261-274). Samo odvajanje obično je vrhunac ostalih stresora u obitelji kojoj je dijete izloženo; roditeljski sukob i napetost često prethode i mogu dovesti do problema $\mathrm{s}$ ponašanjem kod djeteta. Mnogo djece pokazuje promjene u ponašanju u prvoj godini razdvajanja roditelja. Iako se većina problema $\mathrm{s}$ prilagodbom riješi u dvije do tri godine nakon razdvajanja, djetetov osjećaj gubitka može trajati godinama, s pogoršanjem tijekom praznika, rođendana $\mathrm{i}$ drugih posebnih događaja (Kleinsorge, Covitz, 2012: 147-154). Prilagođavanje novoj životnoj situaciji, stalna roditeljska napetost $\mathrm{i}$ otuđenost mogu kod djeteta izazvati cijeli niz problema (Cohen, 2002: 1019-1023).

Demografija obitelji se mijenja, a $\mathrm{s}$ time se mijenjaju i filozofske osnove odnosa.
Mnogi mladi odrasli osjećaju da je brak staromodan i ograničen, a da otvoreni zajednički odnosi pružaju zdraviju mogućnost koja više pogoduje osobnom razvoju. Ako veza ne pruža osobnu sreću, roditelji često vjeruju da će se njihova djeca prilagoditi novim obiteljskim odnosima, tako da će razvod ili razdvajanje imati dugoročne, štetne posljedice. Ova uvjerenja dovela su do toga da se brak ostvaruje kasnije, žene imaju manje djece $i$ to kasnije u životu, te je sve manje djece koja žive sa svojim biološkim roditeljima.

Godine 1960. prosječna dob prvog braka bila je 20,3 godine, to je kod muškaraca bilo u prosjeku 22,8 godina. No do sada, to se promijenilo tako da je medijan stupanja u prvi brak 25,8 godina za žene i 28,3 godine za muškarce. Godine 1960. stopa žena u braku iznosila je 76,5 na 10000 , ali to se smanjilo na 37,4 na 10000 do 2008. (Copen, Daniels, Vespa, Mosher, 2006-2010). Godine 1970. $84 \%$ djece živjelo je s biološkim roditeljima koji su bili u braku, dok je do 2009. bilo 60\% u navedenim uvjetima. U 2009. godini samo $29 \%$ djece živjelo je s biološkim roditeljima koji su u braku, dok je 50\% živjelo sa samohranom majkom. Ono što je također važno, utvrđeno studija koja je provedena od strane Sveučilišta Harvard, najistaknutiji faktor koji većini djece sprječava povoljan razvoj jest život s jednim roditeljem (Chetty, Hendren, Kline, Saez, 2014). Pored toga, broj parova koji se odluče za zajednički život, 
umjesto da se vjenčaju, dramatično je porastao, sa 4,9 milijuna parova koji žive zajedno 2002. godine, nasuprot samo 500000 iz 1970. godine (Američki popisni ured, 2003). Podatci iz, primjerice američke literature, ukazuju da je polovica djece rođenih izvan braka, a u zajedničkom partnerskom odnosu muškarca i žene, te da će sedmero od desetero djece takvih parova doživjeti raskid odnosa svojih roditelja. Brzina raskida takvih parova četiri je puta veća od parova koji u braku koji nisu zajednički živjeli prije braka (Osborne, Manning, Stock, 2007: 1345-1366).

Centri za kontrolu bolesti prestali su prikupljati cjelovite podatke o broju djece zahvaćene razvodom 1988. godine, a u to je vrijeme bilo pogođeno više od milijun djece (Cohen, 2002: 1019-1023). Od tada se učestalost razvoda i dalje povećava, a prema istraživanju američke zajednice iz 2009. samo $45,8 \%$ djece dostiže 17 godina života a da $\mathrm{i}$ dalje živi sa svojim biološkim roditeljima koji su bili u braku prije ili oko vremena djetetovog rođenja (Fagan, Zill, 2011). Većina razvoda pogađa mlađu djecu jer se $72 \%$ razvoda događa tijekom prvih 14 godina braka. Budući da se visoki postotak razvedenih odraslih ponovno vjenča, a $40 \%$ tih ponovnih brakova također završava razvodom, djeca mogu biti izložena višestrukim obiteljskim preinakama (Cohen, 2002: 10191023). Uzroci razvoda također su se vremenom mijenjali. Prije zakona o razvodu gdje nitko ne snosi krivnju, zakonski postupci za razvod braka često su bili dugotrajni i skupi, tako da su razvodom završili samo uvelike disfunkcionalni brakovi. Djeca koja su uklonjena iz disfunkcionalnog okruženja imaju veću vjerojatnost da će nakon razvoda biti bolje. Međutim, uvođenjem spomenutog zakona o razvodu vjerojatnije je da dijete nije doživjelo utjecaj ozbiljnog roditeljskog razdora, pa razvod ima više štetnih učinaka na dijete. Jednom je studijom utvrđeno da većini novijih razvoda nije prethodilo dugo razdoblje bračnog sukoba (Amato, 2001: 355-375). Razvod i razdvajanje roditelja štete djeci, obiteljima, gospodarstvu i društvu u cjelini. Iako neće sva djeca ili roditelji doživjeti baš sve negativne posljedice, obzirom na ozbiljnost nepovoljnih ishoda i opseg problema, važno je naglasiti promicanje i očuvanje djetetove biološke obitelji. Kada se govori o znanstvenim istraživanjima o učincima razvoda na djecu i roditelje, važno je uzeti u obzir sve čimbenike koji utječu na ishod, uključujući obiteljsku dinamiku, temperament $\mathrm{i}$ dob djece $\mathrm{u}$ vrijeme razvoda $\mathrm{i}$ obiteljski socioekonomski status, kao i bilo kakva pitanja ponašanja ili brige i obaveze prije razvoda. Neki štetni učinci zabilježeni u literaturi nakon razvoda zapravo se smanjuju ako se detektiraju prije razvoda. Važno je također napomenuti da nasilje u kući nikada nije prihvatljivo i može imati ozbiljne štetne učinke na dječje ponašanje, razvoj, akademski uspjeh i zdravlje u budućnosti. 
M. Jakelić, A. Mutić, D. Protić, Kvaliteta života djece razvedenih roditelja

Svako dijete i svaka obitelj očito su jedinstveni, s različitim snagama i slabostima, različitim osobnostima i temperamentima, različitim stupnjevima socijalnih, emocionalnih i ekonomskih resursa, kao i različitim obiteljskim situacijama prije razvoda. Unatoč tim razlikama, dokazano je da razvod smanjuje djetetovu buduću kompetenciju u svim područjima života, uključujući obiteljske odnose, obrazovanje, emocionalno blagostanje i buduću zaradu. Iako u dobi adolescencije djeca mogu razumjeti neke od razloga za raspad obitelji, možda još uvijek teško prihvaćaju situaciju i mogu pokušati preuzeti ulogu odraslih (Clarke-Stewart, Vandell, McCartney, Owen, Booth, 2000: 304-326). Može deidealizirati jednog ili oba roditelja i još uvijek vjerovati da mogu ponovno ujediniti roditelje. Agresivno delinkventno ponašanje, povlačenje, zloupotreba opojnih supstanci, neprimjereno seksualno ponašanje i loši školski rezultati česti su odgovori na promjenu obiteljske strukture (Sentse, Ormel, Veenstra, Verhulst, Oldehinkel, 2011: 97-106). Suicidne misli su učestalije kod dječaka mlađe srednjoškolske dobi, odvojenih od majki i češća je $u$ muškaraca. Djevojke koje žive s razvedenim očevima imaju veću vjerojatnost da će pokušati samoubojstvo od djevojčica koje žive s razvedenim majkama (Lizardi, Thompson, Keyes, Hasin, 2009: 899-904). Različite situacije i aktivnosti mogu imati različite učinke na djecu tijekom razvoda i razdvajanja.
Međutim, ako roditelj ne razumije djetetove individualne potrebe, dijete će vjerojatno biti frustrirano i demonstrirati eksternalizirajuće ponašanje, poput oporbenog ponašanja i općeg lošeg djelovanja. Odstupanje od poznatog miljea može biti negativan čimbenik $u$ prilagođavanju djeteta; djeca koja se odsele iz svog nekadašnjeg doma vjerojatno će osjetiti veće posljedice (Braver, Ellman, Fabricius, 2003: 206-219). Jedan pregled literature proveden u Ujedinjenom Kraljevstvu pokazao je da ,iako su djeca izložena povećanom riziku od štetnih ishoda nakon raspada obitelji i da negativni ishodi mogu biti prisutni i u odrasloj dobi, razlika između djece iz netaknute i raspadnute obitelji je mala“, a većina djece neće dugoročno biti podložna negativnim utjecajima (Mooney, Oliver, Smith, 2009). Međutim, postoji mnogo istraživanja koja nude suprotne dokaze. Dvije velike meta analize, jedna provedena 1991., a druga deset godina kasnije 2001., pokazala su $\mathrm{da} \mathrm{su}$,djeca s rastavljenim roditeljima nastavila znatno niže ocjenjivati svoja obrazovna postignuća, ponašanja, psihološko prilagođavanje, samo-koncepte (samopoštovanje, samopouzdanje) i društvene odnose" (Amato, Keith, 1991: 26-46). Ta su istraživanja ukazala da, kad dijete doživi razvod roditelja, postoje značajni gubici $u$ svim aspektima djetetova života.

Rast globalnih stopa razvoda rezultirao je povećanom usredotočenošću na utjecaj razvoda na djecu. Hogan, Halpenny i Greene 
istaknuli su prednosti istraživanja među samom djecom o njihovim iskustvima povezanim s tranzicijom, a ne o posredovanju samo među odraslima (Hogan, Halpenny, Greene, 2003: 163-80). Razumijevanje iskustava i percepcija djece u vezi s razvodom roditelja mora biti od koristi svim stručnjacima poput psihologa, zdravstvenih radnika, socijalnih radnika i učitelja; moraju pomoći razvoju programa intervencija a $\mathrm{s}$ ciljem boljitka kvalitete života djece razvedenih roditelja.

Razvod roditelja smatra se jednim od najstresnijih događaja u životu djece, s trajnim

\section{CILJ}

Utvrditi zadovoljstvo životom kod djece čiji su roditelji razvedeni.

\section{HIPOTEZA ISTRAŽIVANJA}

Kvaliteta života djece razvedenih roditelja umanjena je $\mathrm{u}$ odnosu na djecu roditelja $\mathrm{u}$ braku.

\section{MATERIJAL I METODE}

Istraživanje je provedeno anonimnom anketom $\mathrm{u}$ srednjim medicinskim školama grada Zagreba. Statističkom obradom uspoređeni su učenici roditelja koji nisu rastavljeni, učenici roditelja koji jesu rastavljeni, učenici koji imaju samo jednog roditelja. $\mathrm{Za}$ usporedbu učenika prema posljedicama na dječji život (Stadelmann, Perren, Groeben, von Klitzing, 2010: 92-108). Pregledom dostupne literature i činjenica $u$ gore navedenom tekstu, većina znanstvenika se slaže da djeca imaju poteškoće $\mathrm{s}$ prilagođavanjem tijekom više mjeseci, a neki i trajno, nakon razvoda roditelja. Način na koji se djeca prilagođavaju tim poteškoćama prvenstveno je posredovan njihovim iskustvom razvoda roditelja (Maes, De Mol, Buysse, 2012: 266-279). To naglašava potrebu za daljnjim studijama koje uzimaju u obzir djetetovu perspektivu, a na čiju temu je provedeno $i$ istraživanje za potrebe ovog rada.

kvantitativnim varijablama korišten je t-test, dok je za usporedbu učenika prema kvalitativnim varijablama korišten hi-kvadrat test. Varijable uključene obradu podataka predstavljaju kvalitativne i kvantitativne varijable. Kvantitativne varijable su varijable iz upitnika Indeks osobne kvaliteta života na kojima su podaci iskazani pomoću Likertove skale od 11 stupnjeva (0-10). Sve preostale varijable su kvalitativne. Kvantitativne varijable prikazane su pomoću aritmetičke sredine, standardne devijacije te minimalne i maksimalne vrijednosti. Kvalitativne varijable prikazane su pomoću apsolutnih i relativnih frekvencija. Za obradu podataka korišten je program IBM SPSS Statistics 20, a dobiveni podaci prikazani su tablično i grafički. 
M. Jakelić, A. Mutić, D. Protić, Kvaliteta života djece razvedenih roditelja

\section{REZULTATI}

\section{Tablica 1.}

DOB - ukupno

\begin{tabular}{cccccc}
\hline \multirow{2}{*}{ ob } & N & M & SD & Min & Max \\
\cline { 2 - 6 } & 144 & 18,30 & 0,70 & 17 & 21
\end{tabular}

Prosječna dob učenika uključenih u istraživanje iznosi 18,3 godine, odnosno 18 godina i 4 mjeseca. Najmlađi učenik ima 17, a najstariji 21 godinu.

\section{Tablica 2.}

SPOL - Ukupno

\begin{tabular}{lcc}
\hline Spol & N & N (\%) \\
\hline Muški & 41 & $28,3 \%$ \\
Ženski & 104 & $71,7 \%$ \\
\hline
\end{tabular}

U istraživanju je sudjelovalo $28,3 \%$ učenika i 71,7\% učenica.

\section{Tablica 3.}

OBRAZOVANJE OCA

\begin{tabular}{lcc}
\hline Obrazovanje oca & N & N (\%) \\
\hline Završena osnovna škola & 2 & $4 \%$ \\
Završena srednja škola & 37 & $74 \%$ \\
Završen studij & 8 & $16 \%$ \\
Završen magisterij/doktorat & 2 & $4 \%$ \\
Student & 1 & $2 \%$ \\
\hline
\end{tabular}

Većina učenika ima oca sa završenom srednjom školom (74\%), a slijede ih oni čiji je otac završio studij (16\%). 4\% učenika ima oca sa završenom školom i završenim magisterijem/doktoratom, a samo jedan učenik navodi da mu je otac student $(2 \%)$.

\section{Tablica 4.}

OBRAZOVANJE MAJKE

\begin{tabular}{lcc}
\hline Obrazovanje majke & N & N (\%) \\
\hline Završena osnovna škola & 2 & $4 \%$ \\
Završena srednja škola & 40 & $80 \%$
\end{tabular}


Završen studij

Završen magisterij/doktorat

Student

Najveći je broj učenika čija majka ima završenu srednju školu (80\%), a slijede ih učenici čija majka ima završen studij (14\%). 4\% učenika ima majku sa završenom osnovnom školom, a 2\% učenika ima majku sa završenim magisterijem/doktoratom. Ni jedan učenik nema majku koja je studentica.

\section{Tablica 5.}

OBITELJSKI STATUS - 2 skupine

\begin{tabular}{lllll}
\hline Obiteljski & status & - & N
\end{tabular}

\section{Roditelji}

\begin{tabular}{lll}
\hline Nisu rastavljeni & 95 & $65,5 \%$ \\
Rastavljeni & 50 & $34,5 \%$
\end{tabular}

U istraživanju je sudjelovalo 64,5\% učenika čiji roditelji nisu rastavljeni i 34,5\% učenika čiji su roditelji rastavljeni.

\section{Tablica 6.}

OBITELJSKI STATUS - 3 skupine

\begin{tabular}{lllll}
\hline Obiteljski & status & - & N & N (\%) \\
Roditelji & & & & \\
\hline
\end{tabular}

\begin{tabular}{lcc}
\hline Oba roditelja & 78 & $53,8 \%$ \\
Jedan roditelj & 17 & $11,7 \%$ \\
Rastavljeni & 50 & $34,5 \%$ \\
\hline U istraživanju je sudjelovalo 53,8\% učenika koji imaju oba roditelja te $11,7 \%$ učenika koji imaju \\
jednog roditelja, a koji nisu rastavljeni. $34,5 \%$ učenika uključenih u istraživanje ima rastavljene \\
roditelje.
\end{tabular}

\section{Tablica 7.}

INDEKS OSOBNE KVALITETE ŽIVOTA

\begin{tabular}{lccccc}
\hline Stupanj zadovoljstva & N & M & SD & Min & Max \\
\hline Životom općenito & 106 & 7,85 & 2,12 & 0 & 10 \\
\hline Životnim standardom & 144 & 7,93 & 2,33 & 0 & 10 \\
\hline
\end{tabular}


M. Jakelić, A. Mutić, D. Protić, Kvaliteta života djece razvedenih roditelja

\begin{tabular}{llllll}
\hline Zdravljem & 145 & 7,97 & 1,98 & 2 & 10 \\
\hline Onime što postižete u životu & 145 & 7,36 & 2,02 & 1 & 10 \\
\hline Odnosima s bližnjima & 145 & 7,88 & 2,56 & 0 & 10 \\
\hline Osjećajem vlastite sigurnosti & 145 & 7,79 & 2,24 & 0 & 10 \\
\hline $\begin{array}{l}\text { Osjećajem pripadanja zajednici } u \text { kojoj } \\
\text { živite }\end{array}$ & 145 & 8,01 & 2,09 & 0 & 10 \\
\hline Osjećajem sigurnosti u budućnosti & 145 & 7,65 & 2,11 & 1 & 10 \\
\hline
\end{tabular}

Podaci u Tablici 7. prikazuju prosječan stupanj zadovoljstva životom općenito i različitim područjima života. Učenici su prosječno u najvećem stupnju zadovoljni osjećajem pripadanja u zajednici u kojoj žive $(M=8,01)$ i zdravljem $(M=7,97)$, dok su u najmanjem stupnju zadovoljni onime što postižu u životu $(\mathrm{M}=7,36)$.

Slika 1.

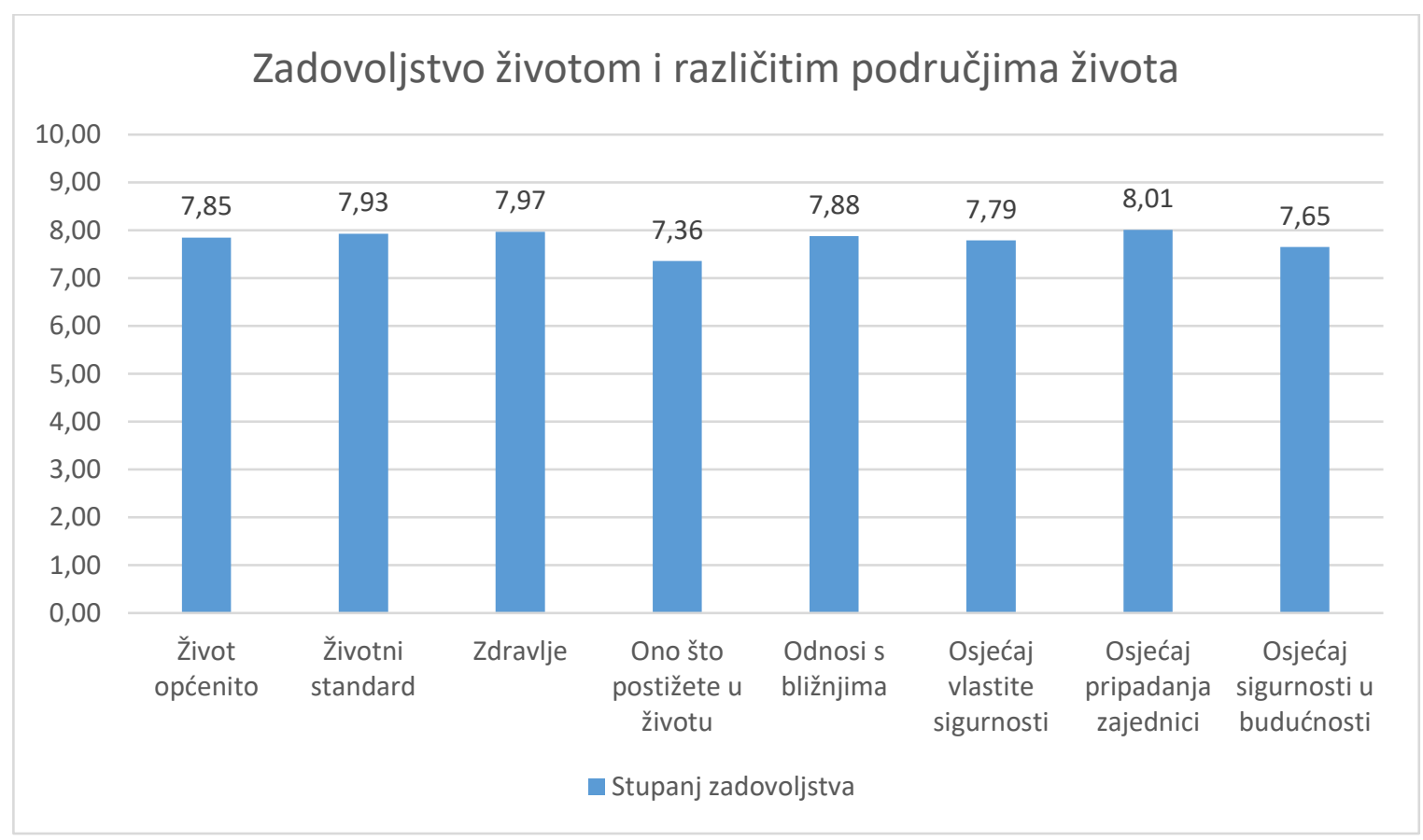

Tablica 8.

INDEKS OSOBNE KVALITETE ŽIVOTA

\begin{tabular}{llccccc}
\hline Stupanj zadovoljstva & Roditelji & N & M & SD & t & p \\
\hline Životom općenito & Nisu rastavljeni & 95 & 8,06 & 1,91 & $\mathbf{2 , 2 5 3}$ & $\mathbf{. 0 4 6}$ \\
\cline { 1 - 1 } & & & & & &
\end{tabular}




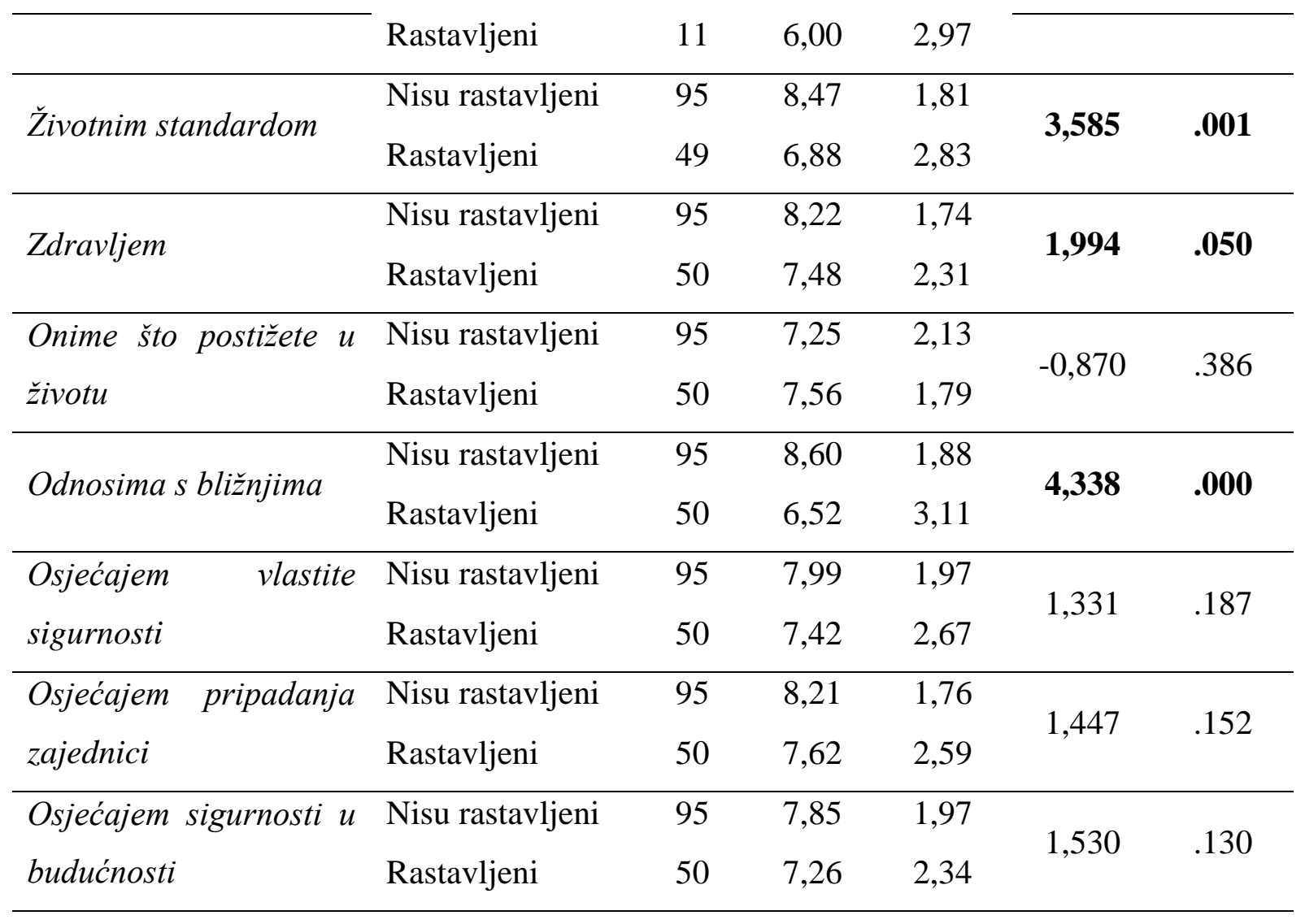

Podaci u Tablici 8. pokazuju kako postoji statistički značajna razlika u stupnju zadovoljstva životom općenito između učenika čiji su roditelji rastavljeni i učenika čiji roditelji nisu rastavljeni $(\mathrm{t}=2,253 ; \mathrm{p}=.046)$. Učenici čiji roditelji nisu rastavljeni su značajno zadovoljniji životom općenito $u$ odnosu na učenike čiji su roditelji rastavljeni.

Također, učenici čiji su roditelji rastavljeni i učenici čiji roditelji nisu rastavljeni statistički se značajno razlikuju i prema stupnju zadovoljstva životnim standardom $(\mathrm{t}=3,585$; $\mathrm{p}=.001), \quad$ zdravljem $\quad(\mathrm{t}=1,994 ; \mathrm{p}=.050) \quad \mathrm{i}$

\section{Tablica 9.}

DOB

\begin{tabular}{llccccc}
\hline \multirow{2}{*}{ oob } & Roditelji & N & M & SD & t & p \\
\cline { 2 - 6 } & Nisu rastavljeni & 95 & 18 & 0 & $\mathbf{- 6 , 2 7 5}$ & $\mathbf{. 0 0 0}$ \\
\hline
\end{tabular}

odnosima $\mathrm{s}$ bližnjima $(\mathrm{t}=4,338 ; \mathrm{p}=.000)$. Učenici čiji roditelji nisu rastavljeni su $u$ većem stupnju zadovoljni životnim standardom, zdravljem i odnosima s bližnjima $\mathrm{u}$ odnosu na učenike čiji su roditelji rastavljeni. Među učenicima čiji su roditelji rastavljeni i onima čiji roditelji nisu rastavljeni ne postoji statistički značajna razlika u stupnju zadovoljstva ostalim ispitivanim područjima života - zadovoljstvo onime što postižu u životu, osjećajem vlastite vrijednosti, osjećajem pripadanja zajednici u kojoj žive i osjećajem sigurnosti u budućnosti. 
M. Jakelić, A. Mutić, D. Protić, Kvaliteta života djece razvedenih roditelja

$\begin{array}{llll}\text { Rastavljeni } & 49 & 18,86 & 0,97\end{array}$

Učenici čiji roditelji nisu rastavljeni i učenici čiji su roditelji rastavljeni koji su uključeni u istraživanje statistički značajno se razlikuju prema prosječnoj dobi $(\mathrm{t}=-6,275 ; \mathrm{p}=.000)$. Prosječna dob učenika čiji roditelji nisu rastavljeni iznosi 18 godina, odnosno svi imaju 18 godina. Prosječna dob učenika čiji su roditelji rastavljeni iznosi 18,86 godina, odnosno 18 godina i 10 mjeseci.

\section{Tablica 10.}

SPOL

\begin{tabular}{lcccc}
\hline Spol & Nisu rastavljeni & Rastavljeni & $\chi^{2}$ & p \\
\hline Muški & $28(29,5 \%)$ & $13(26 \%)$ & 0,195 & .659 \\
Ženski & $67(70,5 \%)$ & $37(74 \%)$ & & \\
\hline
\end{tabular}

Podaci u Tablici 10. pokazuju kako se učenici čiji su roditelji rastavljeni i učenici čiji roditelji nisu rastavljeni ne razlikuju prema spolnoj strukturi. Među obje skupine učenika većina je učenica, u odnosu na učenike.

Tablica 11.

PREBIVALIŠTE

\begin{tabular}{|c|c|c|c|c|}
\hline Prebivalište & Nisu rastavljeni & Rastavljeni & $\chi^{2}$ & $\mathbf{p}$ \\
\hline Grad & $61(64,2 \%)$ & $41(82 \%)$ & \multirow{2}{*}{4,970} & \multirow{2}{*}{.026} \\
\hline Selo & $34(35,8 \%)$ & $9(18 \%)$ & & \\
\hline
\end{tabular}

Podaci u Tablici 11. pokazuju kako među učenicima uključenim u istraživanje postoji statistički značajna razlika u mjestu prebivališta s obzirom na to jesu li im roditelji rastavljeni $\left(\chi^{2}=4,970\right.$; p=.026). Među učenicima čiji su roditelji rastavljeni je, u odnosu na učenike čiji roditelji nisu rastavljeni, veći broj onih koji žive u gradu.

Tablica 12.

INDEKS OSOBNE KVALITETE ŽIVOTA

\begin{tabular}{llccccc}
\hline Stupanj zadovoljstva & Roditelji & N & M & SD & F & p \\
\hline Životom općenito & Oba roditelja & 78 & 8,21 & 1,92 & $\mathbf{6 , 1 8 1}$ & $\mathbf{. 0 0 3}$ \\
\cline { 5 - 7 } & & & & &
\end{tabular}




\begin{tabular}{|c|c|c|c|c|c|c|}
\hline & \multirow[b]{2}{*}{ Jedan roditelj } & \multirow[b]{2}{*}{17} & \multirow[b]{2}{*}{7,41} & \multirow[b]{2}{*}{1,81} & & \\
\hline & & & & & & \\
\hline & Rastavljeni & 11 & 6,00 & 2,97 & & \\
\hline \multirow{3}{*}{ Životnim standardom } & Oba roditelja & 78 & 8,67 & 1,68 & \multirow{3}{*}{10,271} & \multirow{3}{*}{.000} \\
\hline & Jedan roditelj & 17 & 7,59 & 2,15 & & \\
\hline & Rastavljeni & 49 & 6,88 & 2,83 & & \\
\hline \multirow{3}{*}{ Zdravljem } & Oba roditelja & 78 & 8,46 & 1,54 & \multirow{3}{*}{5,902} & \multirow{3}{*}{.003} \\
\hline & Jedan roditelj & 17 & 7,12 & 2,18 & & \\
\hline & Rastavljeni & 50 & 7,48 & 2,31 & & \\
\hline \multirow{3}{*}{$\begin{array}{l}\text { Onime što postižete } u \\
\text { životu }\end{array}$} & Oba roditelja & 78 & 7,47 & 2,04 & \multirow{3}{*}{3,094} & \multirow{3}{*}{.048} \\
\hline & Jedan roditelj & 17 & 6,24 & 2,31 & & \\
\hline & Rastavljeni & 50 & 7,56 & 1,79 & & \\
\hline \multirow{3}{*}{ Odnosima s bližnjima } & Oba roditelja & 78 & 8,76 & 1,79 & \multirow{3}{*}{13,651} & \multirow{3}{*}{.000} \\
\hline & Jedan roditelj & 17 & 7,88 & 2,15 & & \\
\hline & Rastavljeni & 50 & 6,52 & 3,11 & & \\
\hline \multirow{3}{*}{$\begin{array}{l}\text { Osjećajem } \\
\text { sigurnosti }\end{array}$} & Oba roditelja & 78 & 8,13 & 2,00 & \multirow{3}{*}{1,915} & \multirow{3}{*}{.151} \\
\hline & Jedan roditelj & 17 & 7,35 & 1,77 & & \\
\hline & Rastavljeni & 50 & 7,42 & 2,67 & & \\
\hline \multirow{3}{*}{$\begin{array}{l}\text { Osjećajem } \\
\text { zajednici }\end{array}$} & Oba roditelja & 78 & 8,28 & 1,77 & \multirow{3}{*}{1,570} & \multirow{3}{*}{.212} \\
\hline & Jedan roditelj & 17 & 7,88 & 1,73 & & \\
\hline & Rastavljeni & 50 & 7,62 & 2,59 & & \\
\hline \multirow{3}{*}{$\begin{array}{l}\text { Osjećajem sigurnosti } u \\
\text { budućnosti }\end{array}$} & Oba roditelja & 78 & 8,10 & 1,76 & \multirow{3}{*}{4,551} & \multirow{3}{*}{.012} \\
\hline & Jedan roditelj & 17 & 6,71 & 2,49 & & \\
\hline & Rastavljeni & 50 & 7,26 & 2,34 & & \\
\hline
\end{tabular}

Podaci u Tablici 12. pokazuju kako postoji statistički značajna razlika u stupnju zadovoljstva životom općenito između učenika $\mathrm{s}$ različitim obiteljskim statusom $(\mathrm{F}=6,181 ; \mathrm{p}=.003)$. Učenici koji imaju oba roditelja su u najvećem stupnju zadovoljni životom općenito, a učenici rastavljenih roditelja su u najmanjem stupnju zadovoljni životom općenito. Detaljnijom analizom utvrđeno je kako se značajno razlikuju samo učenici koji imaju oba roditelja i učenici rastavljenih roditelja $(\mathrm{p}=.003)$ - učenici koji imaju oba roditelja su značajno zadovoljniji životom općenito od učenika rastavljenih roditelja.

Također, učenici različitog obiteljskog statusa statistički se značajno razlikuju prema stupnju zadovoljstva životnim standardom $(\mathrm{F}=10,271$; 
M. Jakelić, A. Mutić, D. Protić, Kvaliteta života djece razvedenih roditelja

$\mathrm{p}=.000)$, zdravljem $(\mathrm{F}=5,902 ; \mathrm{p}=.003)$, onime što postižu u životu $(\mathrm{F}=3,094 ; \mathrm{p}=.048)$, odnosima s bližnjima $(\mathrm{F}=13,651 ; \mathrm{p}=.000) \mathrm{i}$ osjećajem sigurnosti u budućnosti $(\mathrm{F}=4,551$; $\mathrm{p}=.012$ ). Svim navedenim područjima su $\mathrm{u}$ prosjeku najzadovoljniji učenici koji imaju oba roditelja, osim onime što postižu u životu. Detaljnijom analizom utvrđeno je kako se prema stupnju zadovoljstva životnim standardom $(p=.000)$, i odnosima s bližnjima $(p=.000)$ statistički značajno razlikuju samo učenici koji imaju oba roditelja i učenici rastavljenih roditelja. Učenici koji imaju oba roditelja su u prosjeku zadovoljniji životnim standardom i odnosima s bližnjima u odnosu na učenike čiji su roditelji rastavljeni.

Prema stupnju zadovoljstva zdravljem se učenici koji imaju oba roditelja značajno razlikuju od učenika koji imaju samo jednog roditelja $(p=.026)$ i učenika koji imaju rastavljene roditelje $(p=.015)$. Učenici koji imaju oba roditelja su u prosjeku zadovoljniji zdravljem od učenika koji imaju jednog roditelja i učenika čiji su roditelji rastavljeni. Prema zadovoljstvu onime što postižu u životu značajno se razlikuju samo učenici koji imaju jednog roditelja i učenici čiji su roditelji rastavljeni $(p=.050)$. Učenici čiji su roditelji rastavljeni su u prosjeku zadovoljniji onime što postižu u životu od učenika koji imaju samo jednog roditelja.

Prema zadovoljstvu posljednjim navedenim područjem - osjećajem sigurnosti u budućnosti značajno se razlikuju učenici koji imaju oba roditelja i učenici koji imaju jednog roditelja $(\mathrm{p}=. .033)$. Učenici koji imaju oba roditelja u prosjeku su zadovoljniji osjećajem sigurnosti u budućnosti nego učenici koji imaju jednog roditelja.

Među učenicima različitog obiteljskog statusa ne postoji statistički značajna razlika u stupnju zadovoljstva osjećajem vlastite vrijednosti i osjećajem pripadanja zajednici. 
Slika 2.

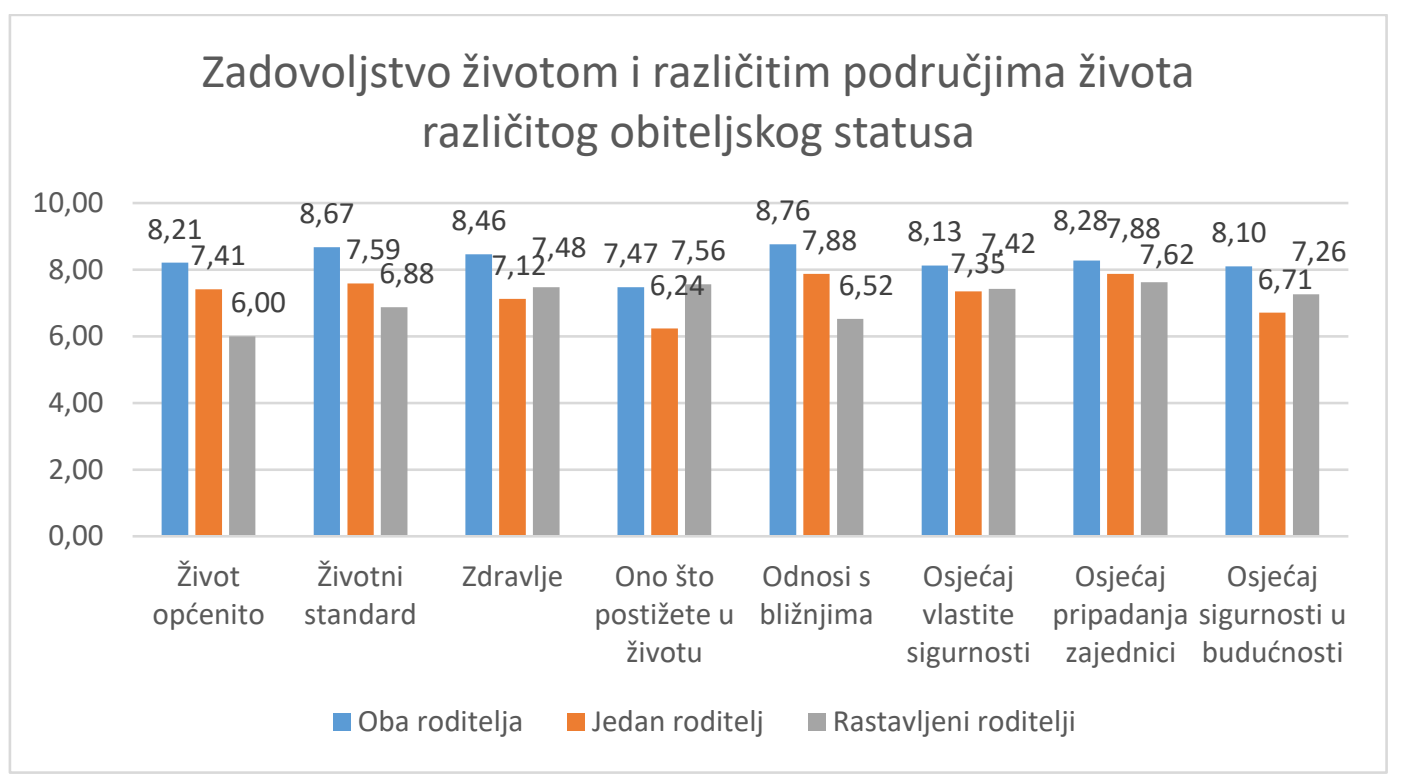

Tablica 13.

DOB

\begin{tabular}{llccccc}
\hline \multirow{4}{*}{ Dob } & Roditelji & N & M & SD & F & p \\
\cline { 2 - 7 } & Oba roditelja & 78 & 18 & 0 & & \\
& Jedan roditelj & 17 & 18 & 0 & $\mathbf{3 8 , 7 7 3}$ & $\mathbf{. 0 0 0}$ \\
& Rastavljeni & 49 & 18,86 & 0,97 & & \\
\hline
\end{tabular}

Podaci u Tablici 13. pokazuju kako se učenici različitog obiteljskog statusa koji su uključeni u istraživanje statistički značajno razlikuju prema prosječnoj dobi $(\mathrm{F}=38,773 ; \mathrm{p}=.000)$. Prosječna dob učenika koji imaju oba ili jednog roditelja iznosi 18 godina, odnosno svi imaju 18 godina. Prosječna dob učenika čiji su roditelji rastavljeni iznosi 18,86 godina, odnosno 18 godina i 10 mjeseci.

\section{Tablica 14.}

SPOL

\begin{tabular}{lccccc}
\hline Spol & Oba roditelja & $\begin{array}{c}\text { Jedan } \\
\text { roditelj }\end{array}$ & Rastavljeni & $\chi^{2}$ & p \\
\hline Muški & $33(29,5 \%)$ & $5(29,4 \%)$ & $13(26 \%)$ & 0,195 & .907 \\
Ženski & $55(70,5 \%)$ & $12(70,6 \%)$ & $37(74 \%)$ & &
\end{tabular}

Podaci u Tablici 14. pokazuju kako se učenici različitog obiteljskog statusa ne razlikuju značajno prema spolnoj strukturi. Među sve 3 skupine većina je učenica, u odnosu na učenike. 
M. Jakelić, A. Mutić, D. Protić, Kvaliteta života djece razvedenih roditelja

Tablica 15.

PREBIVALIŠTE

\begin{tabular}{lccccc}
\hline Prebivalište & Oba roditelja & $\begin{array}{c}\text { Jedan } \\
\text { roditelj }\end{array}$ & Rastavljeni & $\chi^{\mathbf{2}}$ & p \\
\hline Grad & $50(64,1 \%)$ & $11(64,7 \%)$ & $41(82 \%)$ & 4,972 & .083 \\
Selo & $28(35,9 \%)$ & $6(35,23 \%)$ & $9(18 \%)$ & & \\
\hline
\end{tabular}

Podaci u Tablici 15. pokazuju kako među učenicima uključenim u istraživanje ne postoji statistički značajna razlika u mjestu prebivališta s obzirom na njihov obiteljski status $\left(\chi^{2}=4,972 ; p=.083\right)$. Među svim skupinama učenika je većina onih koji žive u gradu.

\section{Tablica 16.}

Pitanje 8. jeste li zadovoljniji životom prije ili poslije razvoda

\begin{tabular}{lll}
\hline Zadovoljstvo životom & N & N (\%) \\
\hline Prije razvoda & 11 & $25,6 \%$ \\
Poslije razvoda & 32 & $74,4 \%$ \\
\hline
\end{tabular}

Većina učenika čiji su roditelji rastavljeni navodi kako su zadovoljniji životom poslije razvoda (74,4\%). 25,6\% učenika smatra da su bili zadovoljniji životom prije razvoda.

\section{Tablica 17.}

Pitanje 9. Tko je rekao da se roditelji razvode

\begin{tabular}{lcc}
\hline Tko je rekao da se roditelji razvode? & $\mathbf{N}$ & $\mathbf{N}(\%)$ \\
\hline Oba roditelja & 4 & $9,5 \%$ \\
Mama & 24 & $57,1 \%$ \\
Tata & 8 & $19 \%$ \\
Obitelj & 5 & $11,9 \%$ \\
Prijatelji & 1 & $2,4 \%$ \\
\hline
\end{tabular}

Većina učenika navodi da ih je mama obavijestila o razvodu (57,1\%). 19\% učenika navodi da ih je obavijestio otac, dok je 11,9\% učenika obavijestila obitelj. 9,5\% učenika su o razvodu obavijestila oba roditelja, dok najmanji broj učenika navodi da su im prijatelji rekli kako se roditelji razvode $(2,4 \%)$. 
Slika 3.

Tko je rekao da se roditelji razvode?

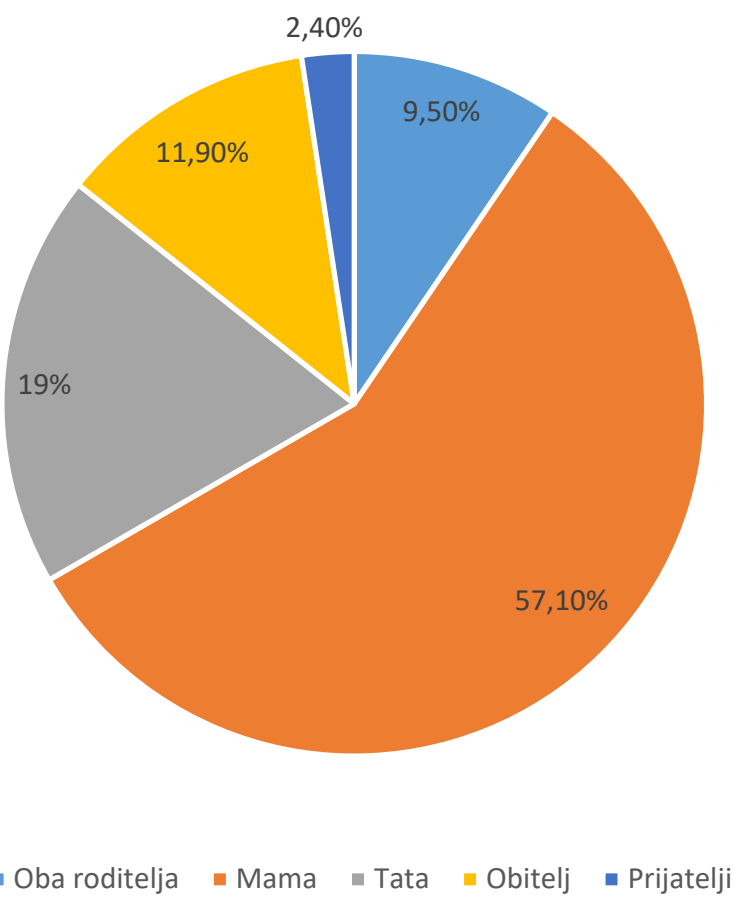

\section{Tablica 18.}

Pitanje 10. Kome Vas je sud dodijelio poslije razvoda

\begin{tabular}{lccc}
\hline $\begin{array}{l}\text { Kome Vas je sud dodijelio poslije } \\
\text { razvoda? }\end{array}$ & N & N (\%) \\
\hline Mami & & 34 & $68 \%$ \\
Tati & 3 & $6 \%$ \\
Ustanova & & 1 & $2 \%$ \\
Suda nije bilo & 12 & $24 \%$ \\
\hline
\end{tabular}

Većina učenika, njih 68\% je sud dodijelio majci, dok je 6\% učenika sud dodijelio ocu. 24\% učenika navodi da suda nije bilo. Samo jedan učenik je dodijeljen u ustanovu (2\%). 
M. Jakelić, A. Mutić, D. Protić, Kvaliteta života djece razvedenih roditelja

Slika 4.

Kome Vas je sud dodijelio poslije razvoda?

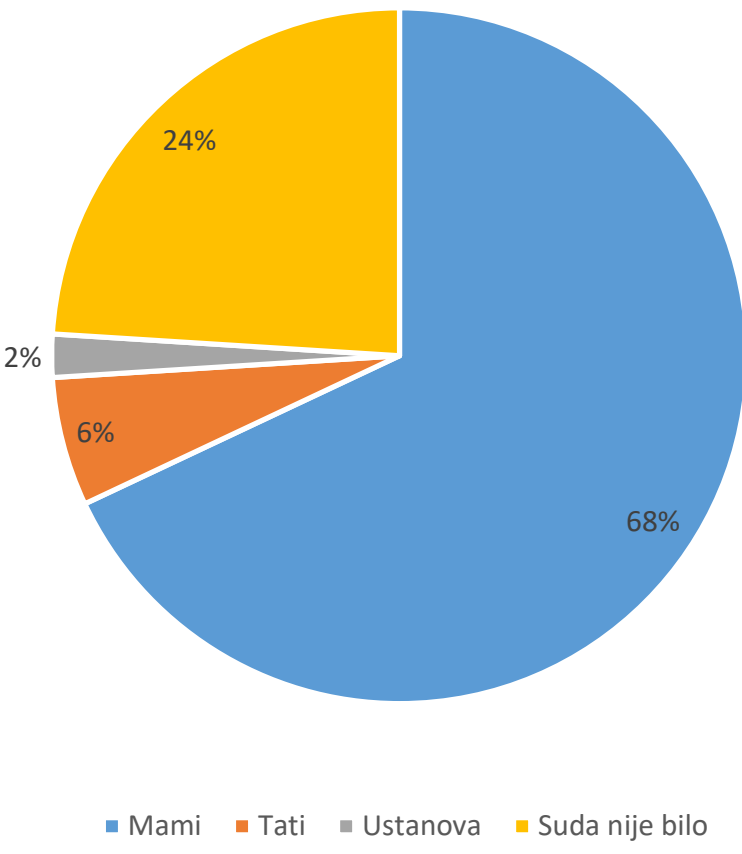

Tablica 19.

Pitanje 11. Da li vas j netko od roditelja primorao da zauzmete njegovu stranu

\begin{tabular}{lcc}
\hline Je li Vas netko od roditelja nagovarao da & $\mathbf{N}$ & $\mathbf{N}(\%)$ \\
zauzmete njegovu stranu? & 19 & $38 \%$ \\
\hline$N e$ & 19 & $38 \%$ \\
Da, mama & 11 & $22 \%$ \\
Da, tata & 1 & $2 \%$ \\
Da, oboje & 1 & \\
\hline
\end{tabular}

Većina učenika navodi da ih je netko od roditelja nagovarao da zauzmu njihovu stranu (62\%), dok $38 \%$ učenika navodi da ih nitko od roditelja nije nagovarao da zauzmu njegovu stranu.

U 38\% slučajeva je majka nagovarala učenika da zauzme njenu stranu, a u 22\% slučajeva je to radio otac. Jedan učenik (2\%) navodi da su ga oba roditelja nagovarali da zauzme njihovu stranu. 


\section{Tablica 20.}

Pitanje 12. Jeste li se osjećali krivima za razvod?

\begin{tabular}{lcccc}
\hline $\begin{array}{l}\text { Jeste li se osjećali krivima za razvod } \\
\text { roditelja? }\end{array}$ & & $\mathbf{N}$ & $\mathbf{N}(\%)$ \\
\hline $\mathrm{Da}$ & & 8 & $12 \%$ \\
$\mathrm{Ne}$ & & 32 & $64 \%$ \\
$\mathrm{Ne}$ sjećam se & & 12 & $24 \%$ \\
\hline
\end{tabular}

Većina učenika, njih 64\% navodi kako se nisu osjećali krivima za razvod roditelja. 24\% učenika se ne sjeća jesu li se osjećali krivima, dok se 12\% učenika osjeća krivima za razvod roditelja.

\section{Tablica 21.}

Pitanje 13. Bi li voljeli da su roditelji ostali u braku?

\begin{tabular}{llc}
\hline Bi li voljeli da su roditelji ostali u braku? & $\mathbf{N}$ & $\mathbf{N}(\boldsymbol{\%})$ \\
\hline $\mathrm{Da}$ & 16 & $32 \%$ \\
$\mathrm{Ne}$ & 19 & $38 \%$ \\
$\mathrm{Ne}$ znam & 15 & $30 \%$ \\
\hline
\end{tabular}

Otprilike je podjednak broj učenika koji bi htjeli i onih koji ne bi htjeli da su roditelji ostali u braku. $32 \%$ učenika bi voljelo da su roditelji ostali u braku, dok $38 \%$ učenika ne bi voljelo da su roditelji ostali u braku. $30 \%$ učenika nije sigurno bi li voljeli da su roditelji ostali u braku.

\section{Tablica 22.}

Pitanje 14. Jesu li roditelji ostali u dobrim odnosima?

\begin{tabular}{lccc}
\hline $\begin{array}{l}\text { Jesu li roditelji ostali } \\
\text { odnosima nakon razvoda? }\end{array}$ & $\mathbf{N}$ & $\mathbf{N}(\%)$ \\
\hline$D a$ & & 21 & $42,9 \%$ \\
$N e$ & & 28 & $57,1 \%$ \\
\hline
\end{tabular}

Više od polovice učenika $(57,1 \%)$ navodi da roditelji nisu ostali u dobrim odnosima nakon razvoda, dok 42,9\% navodi kako su roditelji ostali u dobrim odnosima nakon razvoda. 
M. Jakelić, A. Mutić, D. Protić, Kvaliteta života djece razvedenih roditelja

Tablica 23.

Pitanje 15. Koliko često viđate roditelja u čijem skrbništvu niste?

\begin{tabular}{lcc}
\hline $\begin{array}{l}\text { Koliko često viđate } \text { roditelja u } \\
\text { čijem skrbništvu niste? }\end{array}$ & $\mathbf{N}$ & $\mathbf{N}(\%)$ \\
\hline Prema dogovoru & 3 & $6,1 \%$ \\
Svaki dan & 1 & $2 \%$ \\
1x tjedno & 6 & $12,2 \%$ \\
Više puta mjesečno & 7 & $14,3 \%$ \\
1x mjesečno & 13 & $26,5 \%$ \\
Rjeđe od 1x mjesečno & 6 & $12,2 \%$ \\
Uopće se ne viđamo & 13 & $26,5 \%$ \\
\hline
\end{tabular}

Većina učenika koji imaju rastavljene roditelje, njih 26,5\% navodi da se s roditeljem u čijem skrbništvu nisu viđaju jednom mjesečno ili da se uopće ne viđaju. 14,3\% učenika se s tim roditeljem viđa više puta mjesečno, dok 12,2\% učenika navodi da se s tim roditeljem viđaju jednom tjedno ili rjeđe od jednom mjesečno. $6,1 \%$ učenika se po dogovoru viđa s roditeljem, a samo jedan učenik (2\%) se svaki dan viđa s roditeljem u čijem skrbništvu nije.

\section{Tablica 24.}

Pitanje 16a. Jesu li se roditelji ponovno udali/oženili za neku drugu osobu?

\begin{tabular}{lcc}
\hline $\begin{array}{l}\text { Jesu li se roditelji ponovno udali/oženili } \\
\text { za neku drugu osobu? }\end{array}$ & $\mathbf{N}$ & $\mathbf{N}(\%)$ \\
\hline$D a$ & 23 & $46,9 \%$ \\
\hline$N e$ & 26 & $53,1 \%$
\end{tabular}

Gotovo je podjednak broj roditelja koji su se ponovno udali/oženili i onih koji nisu. Njih 53,1\% se nisu ponovno udali/oženili, dok se $46,9 \%$ roditelja ponovno udalo/oženilo.

\section{Tablica 25.}

Pitanje 16b. Tko se ponovno udao/oženio?

\begin{tabular}{|c|c|c|}
\hline $\begin{array}{l}\text { Tko se ponovno } \\
\text { udao/oženio? }\end{array}$ & $\mathbf{N}$ & $\mathbf{N}(\%)$ \\
\hline Mama & 9 & $39,1 \%$ \\
\hline Tata & 10 & $43,5 \%$ \\
\hline Oboje & 4 & $17,4 \%$ \\
\hline
\end{tabular}


U 43,5\% slučajeva, otac se ponovno oženio, dok se u $39,1 \%$ slučajeva majka ponovno udala. U $17,4 \%$ slučajeva su se oba roditelja ponovno udala/oženila.

\section{Tablica 26.}

Pitanje 17. Slažete li se s novim partnerom vaših roditelja? - samo oni koji su u braku

\begin{tabular}{llllcl}
\hline $\begin{array}{l}\text { Slažete li } \\
\text { roditelja? }\end{array}$ & & novim partnerom & $\mathbf{N}$ & $\mathbf{N}(\%)$ \\
\hline $\mathrm{Da}$ & & & & 14 & $60,9 \%$ \\
$\mathrm{Ne}$ & & & 9 & $39,1 \%$ \\
\hline
\end{tabular}

Većina učenika, njih $60,9 \%$ se slaže s novim partnerom njihovih roditelja, dok se $39,1 \%$ učenika ne slaže s novim partnerom njihovih roditelja.

\section{Tablica 27.}

Pitanje 17. Slažete li se s novim partnerom vaših roditelja? - SVI

\begin{tabular}{lllll}
\hline $\begin{array}{l}\text { Slažete li se } \\
\text { roditelja? }\end{array}$ & & novim partnerom & N (\%) \\
\hline $\mathrm{Da}$ & & 20 & $54,1 \%$ \\
$\mathrm{Ne}$ & & & 17 & $45,9 \%$ \\
\hline
\end{tabular}

Gotovo je podjednak broj učenika koji se slažu s novim partnerom njihovih roditelja i onih koji se ne slažu s novim partnerom. 54,1\% učenika se slaže s novim partnerom njihovih roditelja, dok se 45,9\% učenika ne slaže s novim partnerom.

\section{Tablica 28.}

Pitanje 18. Jeste li nezadovoljni zbog novog partnera? - samo oni koji su u braku

\begin{tabular}{lllll}
\hline $\begin{array}{l}\text { Jeste li nezadovoljni } \\
\text { partnera? }\end{array}$ & zbog novog & $\mathbf{N}$ & $\mathbf{N}(\%)$ \\
\hline $\mathrm{Da}$ & & & 10 & $43,5 \%$ \\
$\mathrm{Ne}$ & & & 13 & $56,5 \%$ \\
\hline
\end{tabular}

Većina učenika, njih 56,5\% navodi kako nisu nezadovoljni zbog novog partnera, dok je 43,5\% učenika nezadovoljno zbog novog partnera. 
M. Jakelić, A. Mutić, D. Protić, Kvaliteta života djece razvedenih roditelja

Tablica 29.

Pitanje 18. Jeste li nezadovoljni zbog novog partnera? - SVI

\begin{tabular}{|c|c|c|c|}
\hline $\begin{array}{l}\text { Jeste li nezadovoljni zbog } \\
\text { partnera? }\end{array}$ & novog & $\mathbf{N}$ & $\mathbf{N}(\%)$ \\
\hline $\mathrm{Da}$ & & 13 & $35,1 \%$ \\
\hline $\mathrm{Ne}$ & & 24 & $64,9 \%$ \\
\hline
\end{tabular}

Većina učenika, njih 64,9\% navodi kako nisu nezadovoljni zbog novog partnera, dok je 35,1\% učenika nezadovoljno zbog novog partnera.

Slika 5.

Jeste li nezadovoljni zbog novog partnera?

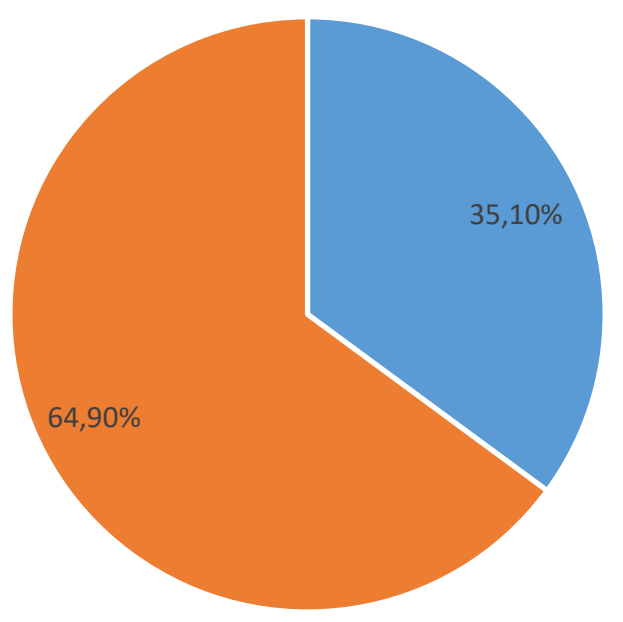

\section{RASPRAVA}

Djetetov glas često se ne čuje u postupku razvoda roditelja (Hogan, O'Reilly, 2007). Upravo tako navode $\mathrm{i}$ autori Chen i George u svom članku: „Među vikanjem postoje glasovi koji se ne čuju: dječji glas“ (Chen, George, 2005: 452-455). U proteklih nekoliko desetljeća istraživači i praktičari sve su više prepoznavali djetetov glas $\mathrm{u}$ domeni života nakon razvoda. Konvencija Ujedinjenih naroda o pravima djeteta pruža djeci pravo na informiranje i izražavanje svog stava u vezi s tim (Van Nijnatten, Jongen, 2011: 540-555). Dječji akt, poseban naglasak stavlja na dječje sudjelovanje u bilo kojem pitanju koje se 
odnosi na dijete. Istraživači su prepoznali prednosti razgovaranja $\mathrm{s}$ djecom izravno o svojim iskustvima, umjesto da se oslanjaju na izvještaje koje daju odrasli (Hogan, Halpenny, Greene, 2003: 163-180).

U svojim istraživanjima o djeci, Hogan i O'Reilly podržavaju djecu kao kompetentne subjekte $u$ društvenim istraživanjima $i$ apeliraju na istraživače da djeci pruže mogućnosti da budu uključena u istraživanja koja se tiču njihovog života (Hogan, O'Reilly, 2007). Roux je utvrdio da se u vrlo malo studija o roditeljskom razvodu razgovara sa samom djecom (Roux, 2007), dok Jeynes (Jeynes, 2001: 125) zagovara razgovor $\mathrm{s}$ djecom i stjecanje njihove perspektive o razvodu roditelja kada god je to moguće. To je posebno važno s obzirom na spoznaju da način na koji djeca percipiraju razvod informira o njihovoj reakciji na događaj razvoda. Nekoliko studija pridonosi trenutnom razumijevanju dječjih iskustava i percepcija u vezi s razvodom roditelja. Djeca izvještavaju o osjećaju bespomoćnosti zbog nedostatka kontrole i ograničenog doprinosa $\mathrm{u}$ vezi $\mathrm{s}$ odlukama vezanim za razvod braka (Biank, Ford Sori, 2003: 15-40). U istraživanju koje je provedeno, otprilike je podjednak broj učenika koji bi htjeli i onih koji ne bi htjeli da su roditelji ostali u braku. $32 \%$ učenika bi voljelo da su roditelji ostali u braku, dok 38\% učenika ne bi voljelo da su roditelji ostali u braku. $30 \%$ učenika nije sigurno bi li voljeli da su roditelji ostali u braku. Istraživanjima je također utvrđeno da djeca percipiraju vlastitu sigurnost i sigurnost tijekom postupka razvoda više nego brigu o sreći svojih roditelja (Bojuwoye, Akpan, 2009: 260-273). Biank i Ford Sori ističu da mlađa djeca ne shvaćaju značenje pojma razvoda i obično se više brinu da roditelji zadovolje njihove potrebe (Biank, Ford Sori, 2003: 15-40).

Hogan i suradnici proveli su kvalitativno istraživanje zasnovano na intervjuu irske djece u dobi od osam do dvanaest godina, usredotočujući se na njihova iskustva promjene obiteljskog života nakon razdvajanja roditelja. Njihovi rezultati pokazali su da se optimalno prilagođavanje dogodilo kada su se djeca osjećala sigurnim u stalnom kontaktu s roditeljem koji nije dobio skrbništvo i kada su dobila uvjerenje da su oba roditelja ostala posvećena svojim odnosima sa djecom. Glavna briga za svu djecu u tom istraživanju bila je priroda kontakta $\mathrm{S}$ roditeljem koji nije skrbnik. Djeca s kojima je proveden razgovor pokazala su sofisticirani kapacitet za opis i konceptualizaciju postupka razvoda roditelja (Hogan, Halpenny, Greene, 2003: 163-80). U istraživanju koje je provedeno, većina učenika koji imaju rastavljene roditelje, njih $26,5 \%$ navodi da se $s$ roditeljem u čijem skrbništvu nisu viđaju jednom mjesečno ili da se uopće ne viđaju. $14,3 \%$ učenika se s tim roditeljem viđa više puta mjesečno, dok 12,2\% učenika navodi da se $s$ tim roditeljem viđaju jednom tjedno ili rjeđe od jednom mjesečno. $6,1 \%$ učenika se po 
dogovoru viđa $\mathrm{s}$ roditeljem, a samo jedan učenik $(2 \%)$ se svaki dan viđa s roditeljem u čijem skrbništvu nije.

Dowling i Gorell-Barnes odvojeno su intervjuirali djecu i njihove roditelje i vodili obiteljske razgovore $\mathrm{s}$ ciljem da utvrde stavove djece o razvodu roditelja. Djeca su roditeljski razvod doživjela i kao pozitivan i kao negativan prijelaz: $\mathrm{s}$ jedne strane su doživjeli olakšanje jer su nestali sukobi i napetosti; a s druge strane doživjeli su značajan gubitak, posebno u pogledu roditelja koji nemaju skrbništvo. Središnja pitanja koja su intervjui iznijeli na površinu uključuju sukob vjernosti djece, kao i njihovu potrebu za koherentnom pričom o razdvajanju roditelja (Dowlin, Gorell-Barnes, 1999: 39-50). U istraživanju provedenom u svrhu izrade rada je otprilike podjednak broj učenika koji bi htjeli i onih koji ne bi htjeli da su roditelji ostali u braku. $32 \%$ učenika bi voljelo da su roditelji ostali u braku, dok $38 \%$ učenika ne bi voljelo da su roditelji ostali u braku. $30 \%$ učenika nije sigurno bi li voljeli da su roditelji ostali u braku.

Dunn i suradnici intervjuirali su uzorak zajednice s 238 djece u Engleskoj u vezi s njihovim iskustvom razvoda roditelja. Mnoga od ove djece doživjela su zbunjenost zbog toga što roditelji nisu mogli objasniti odluke vezane za razvod (Dunn, Davies, O'Connor, Sturgess, 2001: 272-287). Većina učenika u ovom istraživanju navodi da ih je mama obavijestila o razvodu $(57,1 \%)$. 19\% učenika navodi da ih je obavijestio otac, dok je 11,9\% učenika obavijestila obitelj. 9,5\% učenika su o razvodu obavijestila oba roditelja, dok najmanji broj učenika navodi da su im prijatelji rekli kako se roditelji razvode $(2,4 \%)$. Butler i suradnici su istražili iskustva djece o razvodu roditelja na uzorku od 104 djece u dobi od sedam do 15 godina, iz Engleske i Južnog Walesa. Djeca su u navedenoj studiji izvijestila o praktičnim poteškoćama i implikacijama boravka u dva različita doma. Djeca su također govorila o izazovima uživanja u kontaktu sa roditeljima koji nisu skrbnici, dok im je u isto vrijeme nedostajao roditelj skrbnik kada su odvojeni od njih; i obrnuto kad je s roditeljem koji jest skrbnik (Butler, Scanlan, Robinson, Douglas, Murch, 2002: 89-102). Istraživanje o iskustvu tranzicije razvoda na 107 djece s Novog Zelanda, u dobi od sedam do 18 godina, otkrilo je da su djeca željela da budu saslušana tijekom razvodnog postupka i da ne žele biti prisiljena na nešto što im nije ugodno (Smith, Gallop, 2001: 23-31). Najznačajnija tema koja je proizašla iz tog istraživanja bila je važnost informiranja djece, uvažavanja njihovih stavova, slušanja i razmatranja u procesu odlučivanja. Prikladna uključenost u odluke vezane za razvod olakšala je pozitivno prilagođavanje djece. Bojuwoye i Akpan izvijestili su o iskustvima razvoda roditelja desetoro djece iz Južne Afrike u dobi od 13 do 15 godina gdje su otkrili da su dob i spol važni čimbenici koji doprinose percepciji razvoda. U 
nekim su slučajevima djeca izvijestila da su premlada da bi se prisjetila ili razumjela razvod svojih roditelja, dok su se starija djeca uspjela prisjetiti mnogih detalja vezanih uz događaj razvoda. Što se tiče spola, otkriveno je da dječaci i djevojčice različito doživljavaju razvod; s tim da dječaci izražavaju više nezadovoljstva zbog gubitka svojih očeva. Pored toga, Bojuwoye i Akpan su otkrili da obiteljske varijable, uključujući financijski status, ponovni brak roditelja, odnos $\mathrm{s}$ roditeljima koji nisu skrbnici, preseljenje $\mathrm{i}$ stalni sukob između roditelja, također utječu na dječju percepciju i reakcije na razvod roditelja (Bojuwoye, Akpan, 2009: 260-273). Rodriguez i Arnold su u svojoj studiji utvrdili da se dječaci i djevojčice mogu razlikovati u odgovorima na razvod roditelja, osobito tijekom srednjeg djetinjstva i adolescencije. Dok djevojčice imaju veću vjerojatnost da će reagirati u smjeru ,previše kontroliranog“ ponašanja i depresije, dječaci imaju veću vjerojatnost da će razviti probleme $s$ ponašanjem, početi koristiti opojne supstance, napustiti školu i doživjeti pad učinka u školi (Rodriguez, Arnold, 1998: 328-514).

Smatra se da obitelj sačinjena od dva biološka roditelja ima optimalno obiteljsko okruženje za djecu (Storksen, Roysamb, Moum, Tambs, 2005: 725-735). Rezultati istraživanja koji su provedeni među anketiranim učenicima pokazuju kako postoji statistički značajna razlika u stupnju zadovoljstva životom općenito između učenika $\mathrm{s}$ različitim obiteljskim statusom $(\mathrm{F}=6,181 ; \mathrm{p}=.003)$. Učenici koji imaju oba roditelja su u najvećem stupnju zadovoljni životom općenito, a učenici rastavljenih roditelja su u najmanjem stupnju zadovoljni životom općenito. Detaljnijom analizom utvrđeno je kako se značajno razlikuju samo učenici koji imaju oba roditelja i učenici rastavljenih roditelja $(\mathrm{p}=.003)$ - učenici koji imaju oba roditelja su značajno zadovoljniji životom općenito od učenika rastavljenih roditelja. Također, učenici različitog obiteljskog statusa statistički se značajno razlikuju prema stupnju zadovoljstva životnim standardom $(\mathrm{F}=10,271 ; \mathrm{p}=.000)$, zdravljem $(\mathrm{F}=5,902 ; \mathrm{p}=.003)$, onime što postižu u životu $(\mathrm{F}=3,094 ; \quad \mathrm{p}=.048)$, odnosima $\mathrm{s}$ bližnjima $(\mathrm{F}=13,651 ; \mathrm{p}=.000)$ i osjećajem sigurnosti $\mathrm{u}$ budućnosti $\quad(\mathrm{F}=4,551 ; \quad \mathrm{p}=.012) . \quad$ Svim navedenim područjima su u prosjeku najzadovoljniji učenici koji imaju oba roditelja. Adolescenti koji žive u kućanstvima u kojima jedan od bioloških roditelja nije prisutan pokazuju više problema $\mathrm{s}$ prilagodbom i akademskim poteškoćama od adolescenata koji žive $\mathrm{s}$ roditeljima koji su u braku (Fröjd, Marttunen, Kaltiala-Heino, 2011: 1-6). Detaljnijom analizom studije provedene $\mathrm{u}$ srednjim medicinskim školama $\mathrm{u}$ Zagrebu, utvrđeno je kako se prema stupnju zadovoljstva životnim standardom $(\mathrm{p}=.000), \mathrm{i}$ odnosima $\mathrm{s}$ bližnjima $(\mathrm{p}=.000)$ statistički značajno razlikuju samo učenici koji imaju oba roditelja i učenici rastavljenih roditelja. 
Učenici koji imaju oba roditelja su u prosjeku zadovoljniji životnim standardom i odnosima s bližnjima u odnosu na učenike čiji su roditelji rastavljeni. Prema stupnju zadovoljstva zdravljem se učenici koji imaju oba roditelja značajno razlikuju od učenika koji imaju samo jednog roditelja $(p=.026)$ i učenika koji imaju rastavljene roditelje $(p=.015)$. Učenici koji imaju oba roditelja su u prosjeku zadovoljniji zdravljem od učenika koji imaju jednog roditelja i učenika čiji su roditelji rastavljeni. Također, učenici koji imaju oba roditelja u prosjeku su zadovoljniji osjećajem sigurnosti u budućnosti nego učenici koji imaju jednog roditelja. Studija o obrazovnim dostignućima u Norveškoj pratila je 9749 učenika nakon što su završili osnovno obrazovanje, i otkrila je da će adolescenti koji žive $\mathrm{s}$ oba biološka roditelja vjerojatnije završiti srednje obrazovanje nego njihovi kolege koji žive $u$ drugom obliku obiteljske strukture (Markussen, Lodding, Sandberg, Vibe, 2006). Dakle, adolescenti razvedenih roditelja mogu imati niže obrazovne ambicije od svojih vršnjaka iz netaknutih obitelji s dva roditelja. Argument iz ove perspektive je da je svaki od bioloških roditelja važan resurs emocionalne podrške, praktične pomoći, informacija i smjernica. Količina resursa koju djeca gube u odnosu na odsutnost roditelja može ovisiti o faktoru koji je doveo do te odsutnosti. Utvrđeno je da samohrana obitelj zbog razvoda ima više štetnog utjecaja na dobrobit djece nego obitelj s jednim roditeljem zbog smrti roditelja (Amato, 2001: 355-375).

Rezultati istraživanja provedenog $u$ svrhu izrade rada pokazuju da odvajanje od roditelja utječe na kvalitetu života djece. Utvrđeno je kako postoji statistički značajna razlika u stupnju zadovoljstva životom općenito između učenika čiji su roditelji rastavljeni i učenika čiji roditelji nisu rastavljeni $(\mathrm{t}=2,253 ; \mathrm{p}=.046)$. Učenici čiji roditelji nisu rastavljeni su značajno zadovoljniji životom općenito $u$ odnosu na učenike čiji su roditelji rastavljeni. Rezultati upitnika bili su niži kod djece razvedenih roditelja u odnosu na drugu grupuu području različitih domena, poput stupnja zadovoljstva životnim standardom $(\mathrm{t}=3,585 ; \mathrm{p}=.001)$, zdravlja $(\mathrm{t}=1,994 ; \mathrm{p}=.050) \quad \mathrm{i}$ odnosa $\mathrm{s}$ bližnjima $(\mathrm{t}=4,338 ; \mathrm{p}=.000)$. Učenici čiji roditelji nisu rastavljeni su u većem stupnju zadovoljni životnim standardom, zdravljem i odnosima s bližnjima u odnosu na učenike čiji su roditelji rastavljeni. Ovi rezultati podudaraju se s onima koji su zabilježeni u istraživanju kvalitete života provedenom u grupi učenika jedne austrijske škole (FelderPuig, Baumgartner, Topf, Gadner, Formann, 2008: 432-439).

Postoji znatna kontroverza kako ponovni brak utječe na djecu koja su prisiljena prilagoditi se novim normama i obiteljsku dinamiku. No, budući da roditeljsko razdvajanje često uključuje pad prihoda kućanstva, novi bi partner zapravo mogao 
ponuditi dodatnu financijsku potporu. Pored toga, novi bračni par može razviti poboljšani bračni odnos, smanjujući na taj način uznemirujući emocionalni teret djece pretvarajući se u model pozitivnog ponašanja. Prema podatcima ovog istraživanja većina roditelja, njih $64,9 \%$ nisu se ponovno udali/oženili, dok se $35,1 \%$ roditelja ponovno udalo/oženilo. U 43,5\% slučajeva, otac se ponovno oženio, dok se u 39,1\% slučajeva majka ponovno udala. U 17,4\% slučajeva su se oba roditelja ponovno udala/oženila. Većina učenika, njih $60,9 \%$ se slaže s novim partnerom njihovih roditelja, dok se $39,1 \%$ učenika ne slaže s novim partnerom njihovih roditelja. Mnoga su istraživanja utvrdila da djeca iz netaknutih obitelji i djeca iz obitelji s očuhom djeluju podjednako dobro (Pagani, Boulerice, Tremblay, Vitaro, 1997: 769-781).

Razdvajanje roditelja vjerojatno je jedan od najstresnijih događaja koji utječu na djetetov život, uzrokujući raspad obitelji kao modela ponašanja i budućeg zajedničkog života. Konstruktivno suočavanje s krizom može pomoći promicanju djetetovog psihološkog razvoja. To će uglavnom ovisiti o roditeljima, njihovim vještinama rješavanja sukoba te kontroli ljutnje i gubitka, kao i o njihovoj svijesti o djetetovim osjećajima.

Zdravstveni djelatnici mogu naučiti o razvodu ili odvajanju uočavajući promjene ponašanja djece, poteza u obitelji i promjena obiteljske financijske odgovornosti.
Raspitivanje o stresovima u obitelji, uključujući roditeljske poteškoće, može biti rutinski dio posjeta bilo kojem zdravstvenom djelatniku. Kada zdravstveni djelatnik savjetuje obitelj u vezi s pitanjima razvoja i ponašanja djeteta, često se otkrivaju područja bračnog razdora ili stresa. Poznavanje ovih stresora i upućivanje na bračno savjetovanje su prikladni i mogu sačuvati bračni odnos. Vrlo često se slijedom takvo osjetljivih pitanja potiču zdravstveni djelatnici da razmisle o vlastitim stavovima, vjerskim uvjerenjima $\mathrm{i}$ etičkim stavovima u vezi s razvodom, posebno ako su razvod doživjeli u vlastitim obiteljima. Važno je biti što objektivniji u savjetovanju djece i roditelja. Ako se razdvajanje čini točnim, rane intervencije, poput upućivanja na obiteljskog savjetnika, mogu umanjiti roditeljsko neprijateljstvo i pomoći djetetu i roditeljima $\mathrm{u}$ rješavanju obiteljskih poremećaja koji tek dolaze. U slučajevima bračnog razdora potencijalna uloga zdravstvenog djelatnika uključuje uzimanje u obzir djetetove tjelesne i emocionalne potrebe i pažljivo prenošenje roditeljima, osluškujući perspektivu svakog roditelja i sugerirajući im da razmotre savjetovanje $\mathrm{s}$ bračnim savjetnikom kako bi razvili strategije za rješavanje bračnog razdora ili kako bi pomogli djetetu kroz razvod braka. Ukoliko do razvoda dođe, zdravstveni djelatnik bi morao održavati pozitivne, neutralne odnose s oba roditelja i uvijek zastupati interese djeteta. 


\section{ZAKLJUČCI}

1. Kvaliteta života djece razvedenih standardom, zdravljem i odnosima s roditelja umanjena je $\mathrm{u}$ odnosu na djecu roditelja u braku. bližnjima u odnosu na učenike čiji su roditelji rastavljeni.

2. Učenici čiji roditelji nisu rastavljeni su značajno zadovoljniji životom općenito u odnosu na učenike čiji su roditelji rastavljeni.

4. Učenici koji imaju oba roditelja $u$ prosjeku su zadovoljniji osjećajem sigurnosti u budućnosti nego učenici koji imaju jednog roditelja.

3. Učenici čiji roditelji nisu rastavljeni su u većem stupnju zadovoljni životnim

\section{LITERATURA}

1. Kleinsorge, C., Covitz, LM. 2012. Impact of divorce on children: developmental considerations. Pediatr Rev. 33/4. 147-154.

2. Urbano, RC., Hodapp, RM. 2007. Divorce in families of children with Down syndrome: a population-based study. Am J Ment Retard. 112/4. 261-274.

3. Cohen, GJ. 2002. American Academy of Pediatrics Committee on Psychosocial Aspects of Child and Family Health. Helping children and families deal with divorce and separation. Pediatrics. 110/5. 1019-1023.

4. Copen, C., Daniels, K., Vespa, J., Mosher ,WD. National Health Statistics. First Marriages in the United States: Data from the 2006-2010 National Survey of Family Growth. Dostupno na: http://www.cdc.gov/nchs/data/nhsr/nhsr049.pdf; (pristupljeno 20. srpnja 2021.)

5. Chetty, R., Hendren, N., Kline, P., Saez, E. 2014. The Geography of Intergenerational Mobility in the United States Harvard University. Dostupno na: http://obs.rc.fas.harvard.edu/chetty/_geo.pdf . (pristupljeno 20. srpnja 2021.)

6. Osborne, C., Manning, WD., Stock, PJ. 2007. Married and cohabiting parents' relationship stability: A focus on race and ethnicity. J Marriage Fam. 69. 1345-1366.

7. Cohen, GJ. 2002. Helping children and families deal with divorce and separation. Pediatrics. 110.1019-1023.

8. Fagan, PF., Zill, N. 2011. The second annual index of family belonging and rejection. Washington, DC: Marriage and Religion Research Institute. 
9. Amato, PR. 2001. Children of divorce in the 1990s. An update of the Amato and Keith (1991) meta-analysis. J Fam Psychol. 15. 355-375.

10. Clarke-Stewart, KA., Vandell, DL., McCartney, K., Owen, MT., Booth C. 2000. Effects of parental separation and divorce on very young children. J Fam Psychol. 14/2. 304-326.

11. Sentse, M., Ormel, J., Veenstra, R., Verhulst, FC., Oldehinkel, AJ. 2011. Child temperament moderates the impact of parental separation on adolescent mental health: The Trails Study. $J$ Fam Psychol. 25/1. 97-106.

12. Lizardi, D., Thompson, RG., Keyes, K., Hasin, D. 2009. Parental divorce, parental depression, and gender differences in adult offspring suicide attempt. J Nerv Ment Dis. 197/12. 899-904.

13. Braver, SL., Ellman, IM., Fabricius, WV. 2003. Relocation of children after divorce and children's best interests: new evidence and legal considerations. J Fam Psychol; 17/2. 206219.

14. Mooney, A., Oliver, C., Smith, M. 2009. Impact of family breakdown on children's wellbeing evidence review DCSF-RR113; London: University of London, Institute of Education, Thomas Coram Research Unit.

15. Amato, PR., Keith, B. 1991. Parental divorce and the well-being of children: A metaanalysis. Psychological Bulletin. 110. 26-46.

16. Hogan, D., Halpenny, A., Greene, S. 2003. Change and continuity after parental separation: Children's experiences of family transitions in Ireland. Childhood. 10/2.163-180.

17. Stadelmann, S., Perren, S., Groeben, M., von Klitzing, K. 2010. Parental separation and children's behavioral/emotional problems: The impact of parental representations and family conflict. Family Process. 49/1. 92-108.

18. Maes, SDJ., De Mol, J., Buysse, A. 2012. Children's experiences and meaning construction on parental divorce: A focus group study. Childhood. 19/2. 266-279.

19. Hogan, F., O’Reilly, M. 2007. Listening with children: research, policy and practice. Rad prezentiran na međunarodnoj konferenciji: Centre for Early Childhood Development \& Education (CECDE) International Conference Vision into Practice: Making Quality a Reality in the Lives of Young Children. Dublin; Irska: http://repository.wit.ie/545/1/Listening_with_children_Research\%2C_Policy_and_Practice.p df (pristupljeno 25. srpnja 2021.)

20. Chen, JD., George, RA. 2005. Cultivating Resilience in Children From Divorced Families. Family J. 13/4. 452-455. 
M. Jakelić, A. Mutić, D. Protić, Kvaliteta života djece razvedenih roditelja

21. Van Nijnatten, C., Jongen, E. 2011. Professional conversations with children in divorcerelated child welfare inquiries. Childhood. 18/4. 540-555.

22. Roux, LM. 2007. Exploring children's coping with divorce: A phenomenological perspective. (Disertacija) University of the Free State, Bloemfontein, South Africa.

23. Biank, N., Ford Sori, C. 2003. Encouraging children's stories of divorce. Journal of Clinical Activities, Assignments \& Handouts in Psychotherapy. 2/4.15-40.

24. Bojuwoye, O., Akpan, O. 2009. Personal, familial and environmental perspectives in children's reactions to parental divorce in South Africa. J Fam Stud. 15/3. 260-273.

25. Dowlin, E., Gorell-Barnes, G. 1999. Children of divorcing families: A clinical perspective. $J$ Child Psychol Psyc. 4/1. 39-50.

26. Dunn, J., Davies, LC., O’Connor, TG., Sturgess, W. 2001. Family lives and friendships: The perspectives of children in step-, single-parent, and nonstep families. J Fam Psychol. 15/2. 272-287.

27. Butler, I., Scanlan, L., Robinson, M., Douglas, G., Murch, M. 2002. Children's involvement in their parents' divorce: Implications for practice. Children \& Society. 16(2): 89-102.

28. Smith, AB., Gallop, MM. 2001. What children think separating parents should know. NZ J Psychol. 390/1. 23-31.

29. Rodriguez, H., Arnold, A. 1998. Children and divorce: A snapshot. Center for Law and Social Policy; 202. 328-514.

30. Storksen, I., Roysamb, E., Moum, T., Tambs, K. 2005. Adolescents with a childhood experience of parental divorce: A longitudinal study of mental health adjustment. $J$ Adolesc. 28. 725-735.

31. Fröjd S., Marttunen M., Kaltiala-Heino R. 2011. The effect of adolescent- and parentinduced family transitions in middle adolescence. Nord J Psychiatry. 64. 1-6.

32. Markussen, E., Lodding, B., Sandberg, N., Vibe, N. 2006. Difference between people-What does the school do? Rapport 3/2006. Oslo: NIFU STEP.

33. Felder-Puig, R., Baumgartner, M., Topf, R., Gadner, H., Formann, AK. 2008. Health-related quality of life in Austrian elementary school children. Med Care. 46. 432-439.

34. Pagani, L., Boulerice, B., Tremblay, RE., Vitaro, F. 1997. Behavioural development in children of divorce and remarriage. J Child Psychol Psychiatry. 38. 769-781. 
Nastavnička revija 2 (2021) 2, 24-52

\section{SUMMARY}

\section{QUALITY OF LIFE OF CHILDREN OF DIVORCED PARENTS}

Objective: To determine life satisfaction in children whose parents are divorced. Materials and methods: The survey was conducted by an anonymous survey in the secondary nursing schools in Zagreb. Statistical analysis compares students of not divorced parents, students of parents who are divorced, students who have only one parent. A t-test was used to compare students in regard of quantitative variables, while a chi-square test was used to compare students in regard of qualitative variables. The arithmetic mean, standard deviation and minimum and maximum values were used in the data representation. Results: There was a statistically significant difference in life satisfaction in general between students whose parents were divorced and students whose parents were not divorced $(t=2,253 ; p=.046)$. Students whose parents are not divorced are significantly more satisfied with life in general than students whose parents are divorced. Also, students whose parents are divorced and students whose parents are not divorced differ significantly in terms of satisfaction with standard of living $(\mathrm{t}=3,585 ; \mathrm{p}=.001)$, health $(\mathrm{t}=1,994 ; \mathrm{p}=.050)$, and relationships with their closest persons $(\mathrm{t}=4,338 ; \mathrm{p}=.000)$. Students whose parents are not divorced are more satisfied with the standard of living, health and relationships with closest persons than students whose parents are divorced. In satisfaction with what they achieve in life, only students with one parent and students whose parents are divorced differ significantly $(\mathrm{p}=.050)$. Students whose parents are divorced are, on average, more satisfied with what they achieve in life than students who have only one parent. Conclusion: Quality of life of divorced parents children is diminished compared to children of married parents.

Key words: quality of life, children, divorced parents 